\title{
FINANCIAL FEASIBILITY OF SIJUK SHRIMP PASTE BUSINESS IN SUNGAI PADANG VILLAGE, SIJUK DISTRICT, BELITUNG REGENCY
}

\author{
Analisis Kelayakan Finansial Usaha Terasi Sijuk di Desa Sungai Padang \\ Kecamatan Sijuk Kabupaten Belitung
}

\author{
Aditya Nugraha, Suhatmini Hardyastuti, Jangkung Handoyo Mulyo, \\ Faculty of Agriculture, Universitas Gadjah Mada \\ Jl. Flora, Bulaksumur, Kec.Depok, Kabupaten Sleman, \\ Daerah Istimewa Yogyakarta 55281 \\ aceofdemon1899@gmail.com
}

Diterima tanggal 19 April 2017 ; Disetujui tanggal 12 Juni 2017

\begin{abstract}
Sijuk shrimp paste business is a business in processing rebon shrimp which is most commonly implemented in Belitung Regency. Therefore, financial feasibility needs to be done by considering the fluctuation in the number of catches of rebon shrimp in nature that will affect the Sijuk shrimp paste business financially. In this study, profit analysis, investment feasibility, and sensitivity were used to draw the conclusions. The samples involve 25 shrimp paste businesses taken by using census method in Sungai Padang Village, District Sijuk, Belitung Regency. This area is also a central area for producing Sijuk shrimp paste. Census refers to periodic collection of information about the specific population from the entire population. Sampling is a method of collecting information from a sample that represents population. The result showed that the Sijuk shrimp paste businesses gives benefits because they had a gain of Rp.17.558.914,29 / year, the value of gross profit ratio of $50.61 \%$, the rate of return per capital investment of 1.02 , and the return on the investments amounted to $74.58 \%$. The Sijuk shrimp paste businesses are feasible to continue because they had the value of discounted payback period of 1.57 years, the net present value of Rp.18.264.662,44, the internal rate of the return value of 35\%, and the profitability index of 1.78 . From the results of the sensitivity analysis concluded that the Sijuk shrimp paste businesses are feasible to continue because the percentage of increase in the maximum operating costs still can be tolerated which is equal to $44,763 \%$ and the percentage of maximum reduction in the selling price of Sijuk shrimp paste still can be tolerated which is equal to $22.108 \%$.
\end{abstract}

Keyword: Financial feasibility, Sijuk Shrimp Paste Business, Sijuk Distric

\section{INTISARI}

Bisnis terasi udang sijuk adalah bisnis olahan udang rebon yang sebagian besar dilakukan di Kabupaten Belitung. Oleh karena itu, analisis kelayakan keuangan perlu diperhitungkan sesuai dengan fluktuasi hasil tangkapan udang rebon di alam sebab perubahan yang terjadi akan mempengaruhi bisnis ini secara finansial nantinya. Dalam penelitian ini, analisis profit, kelayakan dan sensitifitas keuangan digunakan. Sampel dari penelitian ini melibatkan 25 bisnis terasi udang yang diambil melalui metode sensus di Desa Sungai Padang, Kecamatan Sijuk, Kabupaten Belitung. Area ini merupakan pusat produksi terasi udang sijuk. Sensus merupakan pengambilan informasi secara periodik dari sebuah sampel populasi. Hasil penelitian menunjukkan bahwa terasi udang sijuk memberikan keuntungan sebesar Rp 17.558.914,29/ tahun dengan Gross Profit Ratio sebesar 50.61\%. Tingkat pengembalian 
investasi yang diterima adalah 1.02 dengan laba atas investasi sebesar 74.58\%. NPR bisnis sejumlah $R p$ 18.264.662,44, tingkat pengembalian investasi internal sebesar 35\%, dan indeks profitabilitasnya sebesar 1.78. Selain itu, lama jangka waktu pengembalian discounted adalah 1.57 tahun. Berdasarkan analisis kelayakan tersebut, bisnis terasi udang sijuk termasuk usaha yang layak untuk dijalankan. Hasil analisis sensitifitas juga memberikan kesimpulan yang sama karena peningkatan biaya operasional dan penurunan harga jual secara berurutan mampu mencapai $44.763 \%$ dan $22.108 \%$ (dalam batas wajar).

Kata Kunci: Bisnis Terasi Udang Sijuk, Kawasan Sijuk, Kelayakan Finansial

\section{INTRODUCTION}

Indonesia is a maritime country having abundant fishery resources and diverse. Therefore, many Indonesian people depend on the fishery. However, within the fishery, products are classified into a perishable product, which means it has a short shelf life and is rapidly destroyed. As a result, it will cause the bargaining power of fisherman becoming weaker. Therefore, an attempt to extend the shelf life and to decelerate the rapid deterioration of raw fish products needs to be done, whether become half-finished products or finished products. In general, the method of processing of fishery products carried out by fishermen in Indonesia coast is by drying, brining, smoking, and fermenting. One of Small and Medium-sized Enterprises (SME) processed products made from fishery products which are produced by many coastal fishermen in Indonesia is shrimp paste. According to data from MARS, in 2015 the average market growth of shrimp paste increased by an average value of 22.1 percent per year, while the business value of shrimp paste had increased by an average value of 26.7 percent per year in Indonesia (MARS, 2015).

In Belitung Regency, the shrimp paste businesses have been the longstanding businesses done by fishermen, where people have been employed for more than 20 years (Department of Marine and Fisheries Belitung, 2016). Sijuk shrimp paste business is a business in processing rebon shrimp which is most commonly implemented in Belitung Regency (Table 1).

Table 1. The business category of business in processing rebon shrimp

\begin{tabular}{clc}
\hline No. & \multicolumn{1}{c}{ Business category } & Number \\
\hline 1. & Sijuk shrimp paste business & 25 \\
2. & Rebon shrimp chips & 1 \\
\hline
\end{tabular}

Source: Department of Marine And Fisheries (2016)

In general, Sijuk shrimp paste businesses in Belitung Regency use tiny shrimp called rebon shrimp as the raw material for making the shrimp paste. Rebon is the resource that highly dependent on the stock in nature. This will cause a fluctuation in a number of raw materials that suspected will cause disruption of 
shrimp paste business production activities (Wahyudi, 2015) (Figure 1).

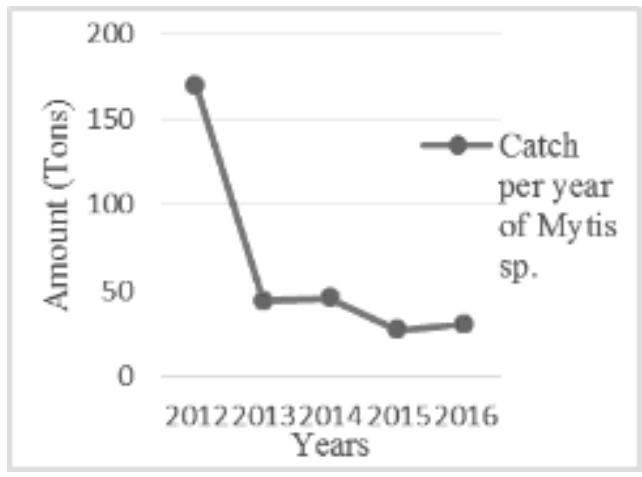

Figure 1. The number of catch per years of Mytis sp.

One of the challenges faced by the development of Sijuk shrimp paste businesses is still weak in management, such as the lack of financial records that cause business owners do not know the financial performances from their businesses so it is difficult to raise capital from the outside institutions (Mutua, 2015).

All the challenges faced by Sijuk shrimp paste businesses effect on the financial aspects such as profitability, investment feasibility and risk level of the business. Therefore, by determining the feasibility of the financial aspects of the Sijuk shrimp paste business will be able to evaluate the business ability to generate revenue and provide an overview of past and present regarding the financial performance of the companies that can aid in decision-making (Classe, 2012).

According to Björnsdóttir (2010), the financial feasibility is divided into four parts: first, an input that consists of the information on investment costs, working capital, financial costs (taxes, dividends, and depreciation), reception. The second part is the financial statements that are comprised of cash flow, income statements, and balance sheet. The third part is the profit analysis and feasibility analysis. The last part is the result of analysis that can be used as a basis for assessing whether the business is profitable and worth continuing or not based on financial aspect.

\section{METHODS}

This research was conducted in Sungai Padang Village, District Sijuk, Belitung Regency. The choice of location is done by purposive sampling because Sungai Padang Village, District Sijuk is a central area for making Sijuk shrimp paste in Belitung Regency (Figure 2.). It is due to elicit the right and the best information to achieve the objectives of the study (Kumar, 2011).

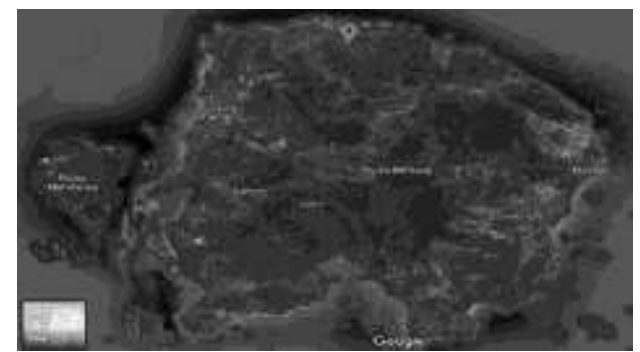

Figure 2. Map Showing the Study Area

The object of this study involved 25 Sijuk shrimp paste small scale businesses and that have been running their businesses 
for more than 5 years. In this study, the primary data is qualitative data which are the general data about the identity of respondents and the data related to Sijuk shrimp paste business activities and the quantitative data are business investment data, production data including the receipt and expenditure of Sijuk shrimp paste business. Secondary data in this study were obtained from the relevant institutes. Primary data collection instruments used in this study was a questionnaire. Results obtained from the questionnaire then analyzed hence easy to interpret (Kumar, 2011). The criteria used to analyze the profitability are as follows:

\section{Profit}

Business profit is the amount of revenue after deducting the expenses incurred for the production process, both fixed cost and variable cost (Primyastanto, 2011).

Profit $=$ Total Revenue - Total Cost

\section{Gross Profit Ratio}

Gross profit ratio is profit compared with the revenue, which can be expressed by the following formula (Dalimute et al., 2015):

Gross Profit Ratio $=\frac{\text { Profit }}{\text { Revenue }} \times 100 \%$

\section{Rate of return per capital invested}

The rate of return per capital invested is a comparison of the profit of the total costs incurred by the formula (Dalimute et al., 2015):

Rate of return per capital invested $=\frac{\text { Profit }}{\text { Total Cost }}$

\section{Return on Investment}

Return on Investment (ROI) is the value of profits earned from the employer any amount of money invested in a certain time period by the formula (Dalimute et al., 2015):

Return of Investment $=\frac{\text { Profit }}{\text { Investment }} \times 100 \%$

The concept of time value of money is very important considering the longer time runs, the value of money is getting down, therefore the investment feasibility analysis using the following criteria, assuming the investment feasibility analyses were age project for 4 years and the discount rate used is the interest rate KUR in 2017 amounted to $13 \%$.

\section{Payback Period}

The feasibility analysis of investment which aims to calculate the length of the investment can be covered by cash inflows in the future which are formulated as follows (Erményi, 2015):

Payback period $=\frac{\text { Total investment }}{\text { Return }}$

\section{Net Present Value}

Represents the difference between the present value of net cash flow or often referred to as proceed with the present value 
of investment formulated by (Gittinger, 1982) in Dolorosa et al., (2014) as follows:

Net Present Value $=\sum_{\mathrm{t}=1}^{\mathrm{n}} \frac{\left(\mathrm{B}_{\mathrm{t}}-\mathrm{C}_{\mathrm{\ell}}\right)}{(1+\mathrm{i})^{\mathrm{t}}}$

where

$\mathrm{n}$ is the age of economic project (year);

$B_{t}$ is the benefits in year $t$;

$\mathrm{Ct}$ is the cost in year $\mathrm{t}$;

$\mathrm{i}$ is the applicable discount factor.

\section{Internal Rate of Return}

The internal rate of return method is a method for finding the discount rate that equates the present value of cash flow to the present value of investment by the formula (Dolorosa et al., 2014) calculated as follows:

$I R R=i_{1}+\frac{N P V^{+}}{N P V^{+}-N P V^{-}}\left(i_{1}-i_{2}\right)$

where

$i_{1}$ is the first interest rate where the NPV is positive;

$\mathrm{i}_{2}$ is the first interest rate where the NPV is negative.

\section{Profitability Index}

Profitability index is investment appraisal method that measures the level of investment feasibility based on the ratio between the total present value of cash inflows and the present value of the total investment by the formula Primyastanto (2011):
Profitability Index $=\frac{\text { Total PV of Cash Inflows }}{\text { PV of the Total Investment }}$

After analyzing the feasibility of investment, the next step needs to perform sensitivity analysis.

\section{Sensitivity Analysis}

The sensitivity analysis is a technique to investigate the impact that inflicted on the future of the change in factors that affect the feasibility of shrimp paste (Nwanekezie et al., 2013). Changes in the value of the investment feasibility analysis criteria such as net present value, internal rate of return, and profitability index on shrimp paste business may occur due to certain changes, such as the decline in product prices and rising operational costs of shrimp paste business. In this study, a sensitivity analysis using a switching value approach to see how big the decline in shrimp product price and an increase in operational costs that allowed so that the shrimp paste businesses do not suffer loss. A sensitivity analysis using replacement value (switching value) to obtain the net present value that close to zero, profitability index approaches a value of 1 , and the value of the internal rate of return approaching the value of discount factor (Dolorosa et al., 2014).

\section{RESULTS AND DISCUSSION}

\section{Sijuk Shrimp Paste Business}

The Sijuk shrimp paste business in Sungai Padang Village, District Sijuk, 
Belitung Regency is still house-scale and still use simple equipment and processing method is still traditional. Sijuk shrimp paste business is a family business that way on the terms of catching and processing experience are passed for generations. The production process of Sijuk shrimp paste business is divided into two activities, capture and processing. On fishing activities, the fishermen use 0.5 GT boat and using gear ancau (net lift) on shrimp season that not very much (April - September) due to morning tides and using fishing gear sero net on shrimp season (October - December) due to night tides and the number of shrimp abundant.

Processing activities, the rebon shrimp that will be made into terasi (shrimp paste) still use conventional way which is first, the process of sorting and washing where rebon captured and have been loaded into the basket are sorted from impurities such as small fish and then washing. The second is the ripening process (fermentation), where the shrimp that has been cleaned and washed put into a sack and fermented with ripened for 24 hours. Furthermore, the third is the drying process, until the shrimp moisture content is reduced and cleaned of dirt. The final process is pulverization process by using a pestle traditional (mortar). In the pulverization process, rebon added enough water. The production of Sijuk shrimp paste in Sungai Padang then marketed. Sijuk shrimp paste marketing process is carried out by the collectors. Collectors collect shrimp paste production then distributed to retail in Tanjungpandan (Belitung Regency). The packaging process is done by the collectors.

\section{Characteristic}

The data of respondents expressed those who were interviewed the housescale business actors in Sungai Padang village. The aspects in question include age, the level of education, experience, and work.

Table 2. The Characteristic of Respondents

\begin{tabular}{lcc} 
Characteristic & Number & Percentage \\
\hline Age (Year): & & \\
$31-40$ & 8 & 32 \\
$41-50$ & 2 & 8 \\
$51-60$ & 12 & 48 \\
\hline Education: & & \\
Elementary School & 25 & 100 \\
\hline Experience (year): & & \\
$<10$ & 9 & 36 \\
$10-20$ & 7 & 28 \\
$>20$ & 9 & 36 \\
\hline Side job: & & \\
Farmer & 25 & 100 \\
Squid fishing & 13 & 52 \\
Sandfish sea & 4 & 16 \\
cucumber fishing & 4 & 16 \\
Crab fishing & 4 & \\
\hline Source: Primary Data Analysis & & \\
Sal & & \\
\hline
\end{tabular}

Source: Primary Data Analysis (2017)

Age is one factor that supports the fishery industries (capturing, culturing, and processing) because it will affect the productivity of fishery business actors. The productive age of fishing communities between 25-59 years. Table 2 above shows that the majority of respondents are in 
the productive age, although there are also some respondents who are not in the productive age anymore. The majority of shrimp paste business actors are in the range of age 25-59 years. For the record, the average production of shrimp paste produced by the entrepreneurs aged 25 59 years is $171.1 \mathrm{~kg} /$ year. Meanwhile, the average production of shrimp paste produced by entrepreneurs aged over 60 years is $140.7 \mathrm{~kg} /$ year. Things that causing the low in production is the declining in physical capabilities of the entrepreneurs resulting less fish haul obtained from catching process.

In general, the education level of fisherman community is still low. Most of the fishermen are only in elementary school level, even some are not finished. The level of education can provide a view of a person's ability to perceive and apply the information and new technologies that could improve the productivity of fishermen. Table 2 showed that the entire shrimp paste business actors in Sungai Padang village (the respondents) have been educated to elementary school level, so it can be concluded that the level of education of the shrimp paste business actors is still low. This will affect the ability in management aspects.

The experience of the shrimp paste business actors is one of the important factors in doing the shrimp paste business, both in catching the rebon shrimp and processing the rebon shrimp into shrimp paste. One of factor that distinguishes the quality of shrimp paste in a region is its human resources including the experience of actors. The fisherman that has experience will become more skilled and have the capacities in catching and processing fish. The experience of shrimp paste business actors in Sungai Padang village comes from trial and error as well as previous businesses. Table 2 showed that all business actors in making shrimp paste can be categorized as very seasoned as they've been doing it for over 4 years.

Shrimp paste business actors in Sungai Padang village made shrimp paste production as their main activity, but because its raw material is seasonal, then to increase their income they have side jobs. Table 2 showed that most of the side job of the shrimp paste business actors is farming pepper and palm oil. This is because farming is not time-consuming and laborious.

\section{Income Flows and Expenditures}

In this study, a description of income flows and expenditures of Sijuk shrimp paste by using the prevailing market price in the area of research.

\section{Income Flows}

The income of Sijuk shrimp paste business actors in Sungai Padang only from selling the shrimp pastes, they do not sell 
Table 3. The Income of Shrimp Paste Business

\begin{tabular}{ccccr}
\hline No & \multicolumn{1}{c}{ Month } & Production $(\mathrm{kg})$ & Price $/ \mathrm{kg}(\mathrm{Rp})$ & \multicolumn{1}{c}{ Income $(\mathrm{Rp})$} \\
\hline 1. & April and May & 55.2 & $120.000,-$ & 6.624 .000 .00 \\
2. & June - September & 61.92 & $135.000,-$ & 8.359 .200 .00 \\
3. & October - December & 189.2 & $110.000,-$ & 19.712 .000 .00 \\
\hline \multicolumn{5}{c}{ Total Income } \\
\hline
\end{tabular}

Source: Primary Data Analysis (2017)

Table 4. The Shrimp Paste Business Investment Cost

\begin{tabular}{|c|c|c|c|c|}
\hline Analysis & $\begin{array}{c}\text { Economic Life } \\
\text { (Year) }\end{array}$ & Amount (Unit) & $\begin{array}{l}\text { Unit Price } \\
\text { (Rupiah) }\end{array}$ & Cost (Rupiah) \\
\hline \multicolumn{5}{|l|}{ Fishing activity } \\
\hline Boat $(0,5 \mathrm{GT})$ & 7 & 1 & 15.000 .000 & 15.000 .000 \\
\hline Sero net & 5 & 1 & 5.000 .000 & 5.000 .000 \\
\hline Ancau net lift & 3 & 1 & 2.000 .000 & 2.000 .000 \\
\hline Baskets & 2 & 2 & 20.000 & 40.000 \\
\hline Flashlights & 2 & 2 & 200.000 & 400.000 \\
\hline Kerosene Lamps & 7 & 1 & 500.000 & 500.000 \\
\hline \multicolumn{5}{|l|}{ Processing } \\
\hline Mortars & 10 & 1 & 500.000 & 500.000 \\
\hline Hoes & 5 & 1 & 75.000 & 75.000 \\
\hline Stoves & 3 & 1 & 250.000 & 250.000 \\
\hline \multicolumn{4}{|c|}{ Total Investment Cost } & 23.545 .000 \\
\hline
\end{tabular}

Source: Primary Data Analysis (2017)

fresh rebon shrimp. The income of shrimp paste business is the total production of shrimp paste multiplied by the selling price. Income from shrimp paste can be seen in Table 3.

Table 3 showed that the highest income was in October - December, this is because in October - December is the season of Mytis sp. thus, the Production rate of shrimp paste is increasing, this will cause income to incerased.

\section{Expenditure Flow}

The expenditures in Sijuk shrimp paste businesses consist of investment costs and operational costs. The investment costs incurred in the early stages before the shrimp business runs which is in year 0 as in the following table (Table 4).

Total cost is all costs incurred annually during the production period, consisting of variable costs and fixed costs. The operational cost of the shrimp paste business can be seen in Table 4. Variable costs have the largest load to be issued by the shrimp paste business actors in Sungai Padang both on fishing activities and processing activities with a total percentage of $61.9 \%$ of total costs. This is consistent with the research conducted by Dalimunte et al., (2015), those variable costs are the largest cost burden on shrimp paste businesses. In fishing activities showed that the biggest expenditure 
Table 5a. The Shrimp Paste Business Total Costs

\begin{tabular}{lcr}
\hline Analysis & & Amount (Rp) \\
\hline Fish Catching & & \\
\hline Fixed Cost & Maintenance Costs & 540.000 .00 \\
& Depreciation Costs & 4.100 .952 .38 \\
Variable Costs & Fuel & \\
& Gas Lamps & 2.112 .000 .00 \\
& Provisions & 540.000 .00 \\
Processing & & 6.960 .000 .00 \\
\hline Fixed Cost & Tarpaulin & \\
& Sacks & 375.000 \\
& Pots & 40.000 \\
& Depreciation Costs & 30.000 \\
Variable Costs & & 148.333 .33 \\
& Labor aside from family members & 1.600 .000 .00 \\
& Water & 86.000 .00 \\
& Kerosene & 604.000 .00 \\
\hline & Total Operational Costs & 17.136 .285 .71 \\
\hline
\end{tabular}

Source: Primary Data Analysis (2017)

Table 5b. The Profit Analysis Criteria

\begin{tabular}{lcr}
\hline Criteria & Unit & \multicolumn{1}{c}{ Value } \\
\hline Profit & Rp/year & $17.558 .914,29$ \\
Gross profit ratio & Percentage & 50,61 \\
Rate of return per capital invested & & 1,02 \\
Return on investment & Percentage & 74,58 \\
\hline
\end{tabular}

Source: Primary Data Analysis (2017)

incurred is provisions and fuel costs. While in processing activities the biggest expenditure incurred is labor costs for non-family labor. In addition to non-family labors, they do it during the shrimp season (October - December) allocated in the drying process.

\section{Analysis Profitability}

The performance and efficiency of a business, in general, can be measured using the financial analysis method by using the ratio of profit. In this study, the ratio of profits that were used are gross profit ratio, operating ratio, return on assets, and return on investment. On the table 5, can be seen on the calculation of profit analysis in Sijuk shrimp pastes businesses in Sungai Padang.

The annual profit that the Sijuk shrimp manufacturing businesses gain is $\mathrm{Rp} .17,558,914.29$. The total profit is considered small. This is because of the number of shrimp production at Sijuk that still exists. According to Aini et al., (2014), the number of production is positively correlated with income of fish processing business. 
Gross profit ratio is based on the correlation between gross profit and income. The value of gross profit ratio of Sijuk shrimp paste business amounted to $50.61 \%$. This percentage has a meaning that from receipts received from $\mathrm{Rp} 1.000,00$ will make a profit of Rp506.1,00. According to Periasami (2010), the high gross profit ratio is an indication of companies that have a high profitability, this also reflects the performance of the business. This is due to the high selling price of Sijuk shrimp paste products in Sungai Padang. The production costs is low as the labors employed are mostly family member and not using highcost technology.

One of the ratios in the profit analysis is the rate of return per invested capital. It is calculated to measure the correlation between the profit and the total cost. The value of the rate of return per invested capital in the Sijuk shrimp paste business is 1.02. It means that from $\mathrm{Rp} 1,00$ of the total cost will generate profits of $\mathrm{Rp}$ $1.02,00$, this value is higher compared to the research of Dalimunte et al., (2015) which is 0,707 . This is due to the cost of the Sijuk shrimp paste businesses are not too large. The larger the index value, the more efficient the businesses (Dalimunte et al., 2015). Sijuk shrimp paste business can be categorized as profitable since the rate of return per invested capital is above the prime lending rate which is $13 \%$ (Osondu and Ijioma, 2014).
Return on investment is the ratio used to measure the amount of return on the investment made. The value return on investment in Sijuk shrimp paste business is $74.58 \%$. The lower the return on investment obtained, the worse the state of a business (less efficient) (Huniyah et al., 2015). The value of the return on investment is influenced by a number of investments in the business and pricing value of products. Karyani (2014) stated that the means of production used by a business is closely related to profits. According to Gregson (2009), giving a good price would result in a reasonable return on investment.

\section{Investment Feasibility Analysis}

One of the components of investment feasibility analysis is an assessment of whether or not the investment to be done by considering the risks inherent in those investments. The analysis used in the calculation of investment feasibility analysis is the discounted cash flow method. Analysis of calculation used in feasibility analysis of investment is discounted cash flow method with a discount rate of $13 \%$ by the age of business/project for 4 years. The selection of the interest rate is based on the prime lending rate that active at this moment, which is in the year 2017. The calculation is carried out on income as the result of shrimp paste sale and expenditure cost that consists of investment costs and operational costs. The investment 
Table 6. The Investment Feasibility Criteria

\begin{tabular}{lcr}
\hline Criteria & Unit & Value \\
\hline Payback period & Year(s) & 1,57 \\
Net present value & Rupiah & $18.264 .662,44$ \\
Internal rate of return & Percentage & 35 \\
Profitability index & & 1,78 \\
\hline
\end{tabular}

Source: Primary Data Analysis (2017).

feasibility analysis measured on Sijuk shrimp paste businesses have the value of investment feasibility that is based on four criteria (Table 6).

On the small-scale business criteria that indicate whether the investment worth or not is the payback period because this criterion measures the payback period of the investment cost from profits by time unit. The Sijuk shrimp paste business value obtained the payback period of 1.57 years. According to Sungun (2015), that if the duration of payback period shorter than the economic life as required, the business is worth to continue.

One of the eligibility criteria of investment feasibility that provides a more cautious approach to assess the investment is the net present value. The Sijuk shrimp paste business in Sungai Padang obtained the value of the net present value of Rp.18.264.662,44. Based on the net present value indicates that the shrimp paste businesses in Sungai Padang are worth continuing, as profits in the future are higher than the cost (Hopkins, 2016).

The internal rate of return shows the ability of capital to provide benefits in the form of the discount rate (El-Tahir and
El-Otaibi, 2014). The value of the internal rate of return on the Sijuk shrimp paste business is $35 \%$. When compared to the rate of return on deposits which is $6.5 \%$, then the Sijuk shrimp paste businesses are worth continuing (Yuwani et al., 2014; Marnis et al., 2016). Profitability index is a significant indicator in assessing the financial performance of a business for calculating the ratio between the present values of net cash inflow in the future with the present value of the investment. The Sijuk shrimp paste businesses obtained the profitability index value of 1.78 . This means that the businesses are worth continuing because the value of profitability index is higher than 1 (Yuwani et al., 2014; Erményi, 2015).

All four of investment feasibility criteria in these studies showed that the Sijuk shrimp paste businesses in Sungai Padang are feasible to continue. This showed that the Sijuk shrimp paste business gives long- term profits commercially (Suad and Suwarsono, 2014). Factors causing businesses like Sijuk shrimp paste in Sungai Padang are the low investment cost and the low rate of interest. Selection of assets is one of the factors that affect the 
feasibility of the investment on a business, this was due to the purchase of assets that is not fixed will cause the fixed costs in a business will be high and reduce the long-term profits (Giovanis and Georgios, 2012). According to Suad and Suwarsono (2014), the interest rate would affect the profitability of an investment.

\section{Sensitivity Analysis}

This uncertainty will affect the profitability of a business because it will reduce profits as a result of increasing costs. Analysis of replacement value (switching value) is done by calculating the maximum change that may occur due to changes in the parameters so that Sijuk shrimp paste businesses remain financially viable. The parameters used are as follows 1) Businesses experienced declining in selling prices of Sijuk shrimp paste while operating costs and other components remain; 2) Businesses experienced increasing in operational costs of Sijuk shrimp paste while revenues and other components remain.

The results of the analysis of switching value calculation obtained the maximum percentage of each sensitivity parameters change of the Sijuk shrimp paste business (Table 7).

Table 7 showed that the Sijuk shrimp paste business actors will not gain profits at the time of the selling price Sijuk hrimp paste products experienced a declining by
Table 7. The Sensitivity Analysis

\begin{tabular}{lc}
\hline \multicolumn{1}{c}{ Parameter } & Value (\%) \\
\hline $\begin{array}{l}\text { Declining in selling price of } \\
\text { Sijuk shrimp paste }\end{array}$ & 22,108 \\
$\begin{array}{l}\text { Increasing in operational costs } \\
\text { of Sijuk shrimp paste }\end{array}$ & 92,495 \\
\hline Source: Primary Data Analysis (2017)
\end{tabular}

$22.108 \%$ and as operating costs increased by $92,495 \%$. The decline in prices of the Sijuk shrimp paste businesses in Sungai Padang caused by selling prices that depend on the decisions decided by the retail, this is because the number of retail that selling Sijuk shrimp paste are only 6. According to Anton et al., (2015), that one of the problems commonly faced by small-medium scale businesses to develop is the limited market information and difficulty in marketing. The result of the analysis of switching value that indicates the maximum limit of the range of changes to the decline in the selling price of sijuk shrimp paste in Sungai Padang village is $22.108 \%$. It indicates that this business is still feasible because the decline in the selling price of sijuk shrimp paste is Rp10.000,00 (9,09\%) with the average of declining in selling price in each season.

The increase in operating costs occurred due to the increase of fuel price so that the price of provisions and fuel supplies themselves go up. This is due to the far distance between Sungai Padang and the gas stations so that the fuel used in the fishing activity has to be bought at retail where the price difference reached Rp.1500/ 
liter and Sungai Padang distance far from the district town which is $45 \mathrm{~km}$ far enough so that it causes supplies price increases. Primsyastanto (2011), that the factor of the location of the fishing industry will affect a number of the production costs of a fishing business. The increase in operational costs of sijuk shrimp paste business has a maximum value of $92.495 \%$. This indicates that this business is still feasible because the increase of its operational costs each year are 17.1 which is the average inflation rate in the study area.

\section{CONCLUSION AND SUGGESTION}

\section{Conclusion}

Based on the criteria of profit analysis is profit, gross profit ratio, the rate of return per capital invested, and return on investments Sijuk shrimp paste businesses in Sungai Padang, District Sijuk, Belitung Regency are feasible to continue. Based on the criteria for investment feasibility analysis, variables such as payback period, net present value, internal rate of return, and profitability index Sijuk shrimp paste businesses in Sungai Padang, District Sijuk, Belitung Regency are feasible to continue. Based on the scenario on switching value analysis, the price reductions of Sijuk shrimp paste in Sungai Padang is $10 \%$, while the increasing in operational cost Sijuk shrimp paste businesses in Sungai Padang is $10 \%$. Thus, the shrimp paste business in this area is feasible to continue.

\section{Suggestion}

The business actors in shrimp paste in Sungai Padang Village can expand their businesses by investing in the freezer box. The government intervention is required for the development of Sijuk shrimp paste in Sungai Padang, for example by providing means of holding exhibitions in each district events and facilities assistance to Sijuk shrimp paste production businesses.

\section{REFERENCES}

Aini, M., Mahyudin, I., Mahreda, E. S. 2014. Analisis Usaha Pengolahan Kerupuk Ikan Gabus (Channa Striata Bloch) Peserta Program Pemberdayaan Konsultan Keuangan Mitra Bank (KKMB) di Kalimantan Selatan (Studi Pemberdayaan KKMB di Kota Banjarmasin). Fish Scientiae 4(7): 23-24.

Anton, S. A., Muzakan, I., Muhammad, W. F., Syamsudin, Sidiq, N. P. 2015. An Assessment of SME Competitiveness in Indonesia. Journal of Competitiveness 7(2): 60-74.

Björnsdóttir, A. R. 2010. Financial Feasibility Assessments: Building and Using Assessment Models for Financial Feasibility Analysis of Investment Projects [thesis]. Reykjavík: Mechanical Engineering and Computer Science School of Engineering and Natural Sciences, University of Iceland.

Claase, M. 2012. Optimizing Feasibility Studies: Based on A Grounded Theory Type Comparison of Feasibility Design Research [thesis]. Enschede: Business Adminstration, University Of Twente. 
Dalimunte, S. A., Ramli, M., Hemdik. 2015. Businesses Producing Terasi In The Village Week Chart Asahan Tanjung Balai Kabupaten Asahan North Sumatra Province. JOM Fakultas Perikanan dan Ilmu Kelautan 2(2).

Dolorosa, E., Masyhuri, Lestari, Jamhari. 2014. Analisis Kelayakan Finansialusaha Perikanan Tambak Polikultur Bandeng-Udang Windu, Jurnal Social Economic of Agriculture 3(2): 20-36.

El-Tahir, Y., El-Otaibi, D. 2014. Internal Rate of Return: A Suggested Alternative Formula and It's MarcoEconomics Implication. Journal of American Science 10(11): 216-221.

Erményi, T. 2015. Evaluating Investment Profitability and Business Controlling Methods. Management, Enterprise and Benchmarking in the 21st Century. http://kgk.uni-obuda. hu/sites/default/files/14_Ermenyi_0. pdf [27 Sepetember 2016].

Giovanis, N. E., Georgios, D. 2012. Reasons for Promoting Fixed Asset Investment Projects in the Region of Greece. The Example of the Prefecture of Serres. International Journal of Business and Social Science 3(14).

Gregson, A. 2009. Pricing Strategies For Small Business. http://www.selfcounsel.com [6 Agustus 2016].

Hopkins, M. 2016. The Case for Project Net Present Value (NPV) and NPV Risk Models. PM World Journal 5(6).

Huniyah, A., Alamsjah, M. A., Pursetyo, K. T. 2015. Analisis Finansial Pembesaran Ikan Bandeng (Chanos chanos) Pada Tambak Tradisional dengan Sistem Monokultur dan Polikultur Di Kecamatan Mulyorejo, Surabaya, Jawa Timur. Jurnal Ilmiah Perikanan dan Kelautan 7(2).
Karyani, U., Mulyono, P., Miasa, I. M. 2014. Unjuk Kerja Mesin Juicer Pada Produksi Susu Nabati Untuk Industri Kecil dan Menengah [tesis]. Yogyakarta: Program Magister Sistem Teknik, Universitas Gadjah Mada.

Kumar, R. 2011. Research Methodology A Step By Step Guide For Beginners. New York: SAGE Publications Ltd.

Marnis., Syahrul., Fitri., Mardayulis. 2016. Valuation of Economic Utilization of Fish Processing Waste Patin (Pangasius Hypopthalmus) as an Added Value for Fish Processing Industry Players in the District Kampar, Riau. International Journal of Economics and Finance 8(9).

Mutua, J. M. 2015. Effect Of Bookkeeping On The Growth Of Small And Medium Enterprises In Chuka Town. European Journal of Business and Social Sciences 4(7): 102 - 112.

Nwanekezie, O. F., Iroegbu, A. N., Wogu, C. L., Okorocha, K. A. 2013. Sensitivity Analysis: A Technique for Investigating the Impact of Changes in Project Variables. International Journal of Research Development.

Osondu, C. K., Ijioma, J. C. 2014. Analysis of Profitability and Production Determinants of Fish Farming in Umuahia Capital Territory of Abia State, Nigeria. World Journal of Agricultural Sciences 2(7): 168-176.

Periasamy. 2010. A Textbook Of Financial Cost And Management Accounting. Mumbai: Himalaya Publishing House.

Primyastanto, M. 2011. Feasibility Study Usaha Perikanan (Sebagai Aplikasi Dari Teori Studi Kelayakan Usaha Perikanan). Malang: UB Press.

Suad, H., Surwasono, M. 2014. Studi Kelayakan Proyek Bisnis Edisi 
5. Yogyakarta: Unit Penerbit dan Percetakan STIM YKPN.

Sungun, G. 2015. Capital Investment Decisions In Small And Medium Sized Enterprises In Turkey. European Journal of Accounting Auditing and Finance Research 3(1): 46-55.

Wahyudi, R. 2015. Analisis Pengendalian Persediaan Barang Berdasarkan
Metode Eoq Di Toko Era Baru Samarinda. eJournal Ilmu Administrasi Bisnis 2(1).

Yuwani, S. H., Irham, Jamhari. 2014. Analisis Kelayakan Dan Strategi Pengembangan Usaha Budidaya Ikan Air Tawar Di Kabupaten Sleman. Jurnal Agro Ekonomi 25(2): 135-143. 